\title{
Classroom Assessment: Student Achievement in Mathematics through Formative Assessment
}

\author{
Nur Afni Fitriana \\ Postgraduate School of Mathematics \\ Education \\ Sebelas Maret University \\ Surakarta, Indonesia \\ nurafni.math@gmail.com
}

\author{
Isnandar Slamet \\ Postgraduate School of Mathematics \\ Education \\ Sebelas Maret University \\ Surakarta, Indonesia
}

\author{
Imam Sujadi \\ Postgraduate School of Mathematics \\ Education \\ Sebelas Maret University \\ Surakarta, Indonesia
}

\begin{abstract}
The challenge of teachers in learning activities is how students can achieve learning goals. This article discusses formative assessment applied by teachers in learning mathematics. The subjects in this study are the senior high school mathematics teachers Class X selected randomly in Magetan. In this research, researcher analyzes and describes the assessments applied by teachers as formative assessments. Data were collected through classroom observation and in-depth teacher's interviews. Teachers apply types of formative assessment in learning mathematics as a strategy to achieve learning objectives. The results show that formative assessment in practice can facilitate students and teachers in the learning process. This is because the formative assessment functions as the feedback provider for the students. Feedback has an impact on teachers to organize assessment and support student learning activities. The impact on students is in their learning commitments so that students can maintain their learning achievement.
\end{abstract}

Keywords - formative assessment, student achievement, feedback,

\section{INTRODUCTION}

Assessment is an important tool for identifying educational success [1]. Therefore, assessment as a means for collecting information on students' progress in relation to achievement of learning objectives and providing feedback to inform instruction [2][3][4]. The assessment reformation in mathematics education is changing according to the curriculum changes. The assessment in Indonesia is a competency-based assessment. The results of that assessment can be used by teachers or schools to improve the learning process and the students can change their learning strategies. Teachers not only measure students' progress in learning. The task of teachers also identifies the student's learning needs. The key element in the successful implementation of the assessment is the teacher [5]. Therefore teachers need to consider carefully when developing an implementation strategy.

Focus assessment actually is not assess true or false but how the strategies used by students. The assessment is viewed as an integrated process assessment of the learning process [6]. Tests and exams are the classic ways teachers use to measure students' learning progress. This form is known as summative assessment. Summative assessment is a term refers to the type of assessment associated with accountability and needs to determine the student's performance level in a particular task or in the end of teaching and learning unit [7]. Usually information obtained from this type of assessment used for reporting to parents.

Characteristics of the current assessment approach are not only the assessment of learning but also the assessment for learning. Assessment for learning is the formative assessment to obtain feedback. Formative assessment is a process of teachers and students during teaching that provides feedback to adjust ongoing teaching and learning to improve student achievement of desired teaching outcomes [8]. Budiyono explained that formative assessment gives feedback to students related to the progress achieved, while feedback to teachers is related to the progress of the learning process [9]. It means that formative assessment can identify students' learning needs and respond to student learning needs. Therefore, errors or misconceptions that occur during the learning process can be identified and found the solutions.

In general, the classroom assessment includes all types of formative assessments by teachers [6]. It is done during the learning process gathered with the aim for planning the next steps. Information on student learning is obtained using various methods, such as sharing learning expectations, questioning, feedback, self-assessment, and peer assessment [8][10]. Student engagement actively in the learning process can help them to develop their skills to learn better.

The teacher's challenge in the learning activities is how the students can achieve the learning objectives. Many teachers use formative assessment in Preparing Lesson Plans (RPP), but they have not been encountered the systematically implementation. There are several aspects of formative assessment that make it difficult for teachers to accurately measure the impact of teaching to student's learning. That one of aspects is the vagueness of constitutive and operational definitions directly contributing to the weaknesses found in related research and the scarcity of empirical evidence that identifies best practices relating to formative assessment [11]. This is intended to enable teachers to develop their formative assessment without being limited by certain parameters. 
The use of formative assessment as a learning strategy can improve student achievement in various subjects [12][13][14]. Formative assessments used by teachers as a framework in classroom learning will change teachers' habits in teaching: teachers change how they interact with the students, how teachers guide and prepare learning situations, and how teachers monitor student learning progress. This provides greater support for conducting research where more efficient methodology and design produce more convincing results and understandings about the impact of formative assessment and evaluation on student achievement. The purpose of this study is to explain that based on the theories and the attempts used to explain the possible reasons for improving student achievement.

\section{THEORETICAL FRAMEWORK}

In this section provides a brief overview of classroom assessment in mathematics education, formative assessment and mathematics learning achievement of students.

\section{A. Classroom Assessment in Mathematics Education}

Learning mathematics now viewed as a process of building knowledge in a social and cultural context, and deep understanding, problem solving, and mathematical reasoning have been valuable curricular targets [15]. Along with an understanding of how students learn mathematics, the approach to classroom assessment is called to make students' thinking and teacher's assessment ability is visible. The current assessment does not only happen at the end of learning, but also instead it goes continuously as part of the learning process.

Classroom assessment refers to activities undertaken by teachers in generating and interpreting evidence of student learning and using this evidence to inform the next step [15]. Furthermore, Wiliam explains the main objectives of the assessment is to assess the achievement or level of student's performance (summative), support students learning and inform instructional decisions of teacher (formative), and evaluate the quality of educational programs or institutions (evaluation). As part of the classroom assessment, teachers offer students the opportunity to conduct self-assessment and peer assessment. Teacher class assessment can lead to improved student mathematics achievement [12].

\section{B. Formative Assessment}

Formative assessment occurs during the learning process. Information obtained can be interpreted and used by teachers and students [16]. Classroom assessments based on formative assessment can develop a teacher framework to teach students. It means that learning is constantly moving toward learning goals. Formative assessment is an important tool in the learning process and simultaneously to improve classroom practice and student performance [17].

One way to look at student learning progress is by summative assessment, but this assessment only records student achievement. Formative assessment can be done after students are given a test (summative assessment). Teachers can identify students' difficulties or mistakes through formative assessment, by providing feedback [2]. As a result, previous test given by teachers is no longer a summative assessment but formative assessment.

\section{Student Achievement}

The current assessment should support learning so that all students can successfully meet the standards [18]. Stiggins explains student achievement can be realized through effective assessment, formative, and grade assessment. Assessment should also describe the current state of student achievement. If the assessment is done to improve learning students, then for the next learning students should be better. Teachers should use evidence related to the learning process to guide students in learning. Evidence gathered through assessments is used to encourage students to learn. The study by Stiggins explains that the challenge issued for assessment is to generate facts about achievement. Therefore, the test instrument used by the teacher should be well designed.

Assessment not only gives scores but also must provide an assessment of student learning. Assessment should provide current descriptions of student achievement. In other words, the results of learning should be informed to do better. Student achievement can be known from the test given by the teachers, in this case is summative assessment. Feedback on formative assessment affects the goals of student achievement. Students who pursue performance goals usually show more achievement.

\section{RESEARCH METHOD}

This qualitative descriptive research was conducted to explain how formative assessment was applied by teachers. The subject of this research was teachers in Senior High School. Samples were chosen based on the criteria of mathematics teachers who teach in class $\mathrm{X}$. There were 3 mathematics teachers participating in this research. Data collection was obtained by conducting classroom observation and teacher interviews. Classroom observation was done during the learning of one Basic Competency (KD). Then, the researcher interviewed all teachers after the classroom observation was done. The data obtained from this research was teaching practice of teachers in applying formative assessment which aimed to identify all activities done by teachers and students during the learning process.

\section{RESULTS AND DisCUSSION}

There are many researches which emphasize the use of formative assessment in learning process at class to improve students' achievement. It is noted that students have greater achievements in the classroom when teacher applies formative assessment [12]. Formative assessment is an important tool for simultaneously improving classroom practice and students' performance [17]. Formative assessment serves as an activity to improve learning and facilitate students' understanding [2]. Formative assessment which is given to students positively improves students' math skills [2].

Classroom observation was conducted by the researcher without disturbing the activities of teachers in teaching learning process. Five strategies supporting the use of formative assessment are: clarifying and sharing learning intentions and 
criteria for success; engineering effective classroom discussions, questions, and learning tasks; providing feedback that improve learners; activating students as the owners of their own learning; and activating students as instructional resources for one another [19]. Teachers who use formative assessment continuously look for ways to obtain evidence of students' learning and use this evidence to meet students' learning needs. Assessment results should be used to develop strategies to meet students' needs. When teachers listen to students' responses related to the questions given, they can understand the concepts explained by peer tutors.

Formative assessment is planned by the teachers consciously and continually to obtain evidence of students' performance and use this information to engage students in the learning process. This formative assessment gives feedback both for students and teacher. Students draw feedback related to progress achieved by them meanwhile teachers draw feedback related to learning process which is designed to learning effectiveness [9]. Formative assessment is a process in which evidences obtained from students' learning are collected and instructions are modified to respond the feedback [9]. Effectively, teachers use the evidences which are obtained during the learning process to identify students' misunderstanding and provide feedback to help students' correct their mistakes.

Teachers' feedback involving students in the classroom can provide improvement chance for students and activate students as learning resource for each other [19]. It sounds complicated, but it does not take a long time in practice. The result will be more effective so that teachers and students can enjoy more in learning process. During classroom observation all formative assessment activities are identified. There are many ways to acquire and listen to students' opinion; one of ways is conducted by giving question. Questions can be asked through discussion group or individuals. This method allows teachers to be responsive toward students' understanding, adjust instruction and deal with specific understandings with students individual. The questions from the teachers' only gives impact to students being asked, but this is a formative assessment. Generally, the teachers are satisfied when students actively participate in the learning process.

Feedback in the learning process creates a more communicative condition at class. The feedback is not only provided by teachers, students, peers, and others. The feedback that contributes to the learning process tends to include information about the success criteria in achieving the learning objectives. Teachers can help students by clarifying and achieving goals through the feedback. According to Hattie and Timperley, there is a feedback and classroom model that highlights teacher demands when teaching. First, teachers need to do an effective instruction. Second, teachers need to make an effective feedback. It means that teachers need to make an accurate assessment about when, how, and at what level to provide the feedback.

The test given by the teacher is a means to find out the difficulties experienced by students and to find out how far that difficulty can be known through the feedback. Giving feedback can be done sooner or later, most importantly, the feedback must be given. The feedback to students has an impact on teachers to organize the assessments and support student learning activities. In addition, the impact of giving feedback can improve student's learning commitment. The emphasis on formative assessment in learning allows students to always be involved in the learning process so that students can maintain their learning achievement. As a result, it can effectively improve student achievement [11][14][20].

\section{CONCLUSION}

The formative assessment in mathematics learning, especially giving feedback can be a powerful strategy to support student achievement. This is because the formative assessment applied by the teacher in the learning process can provide students understanding information. Information about student understanding is used to help students assess themselves and improve their performance through the feedback given by the teacher. The information obtained is also used as a learning improvement for teachers for further teaching.

The series of formative assessment types in mathematics learning play role as a strategy to achieve learning objectives. A learning can be said successful if students understand what is learned, what goals, and what students get. Practically, the formative assessment shows that it can facilitate students and teachers in the learning process. This is because the formative assessment function is as a feedback giver. The impact of giving feedback can improve students' learning commitment. The emphasis on formative assessment in learning allows students to always be involved in the learning process so that students can maintain their learning achievement.

\section{ACKNOWLEDGMENT}

The authors thank to the Postgraduate School of Mathematics Education Sebelas Maret University.

\section{REFERENCES}

[1] H. Retnawati , B. Kartowagiran, J. Arlinwibowo and E. Sulistyaningsih, "Why are the mathematics national examination items difficult and what is teachers' strategy to overcome it?," International Journal of Instruction, vol. 10, pp 257-276, 2017.

[2] K. M. Cauley and J. H. McMillan, "Formative assessment techniques to support student motivation and achievement," The Clearing House, vol. 83, pp. 1-6, 2010.

[3] T. T. Lam, Q. K. Seng, L. Y. Hoong, J. Dindyal, and T. E. Guan, "Assessing problem solving in the mathematics curriculum: A new approach," in Assessment in the mathematics classroom Yearbook 2011, B. Kaur, W. K. Yoong, Eds. Singapore: World Scientific Publishing Co. Pte. Ltd., 2011, pp. 33-66.

[4] I. Clark, "Formative assessment: Assessment is for self-regulated learning," Educational Psychology Review, vol. 24, pp. 205-249, 2012.

[5] R. Berry, "Educational assessment in mainland China, Hong Kong and Taiwan," in Assessment reform in education, R. Berry and B. Adamson, Eds. Netherlands: Springer, 2011, pp. 49-61.

[6] X. Zhao, M. Van den Heuvel-Panhuizen, and M. Veldhuis, "Classroom assessment in the eyes of Chinese primary mathematics teachers: A 
review of teacher-written papers," Studies in Educational Evaluation, vol. 52, pp. 42-54, 2016.

[7] T. Glasson, "Improving student achievement through assessment for learning," Curriculum Leadership, vol. 6, 2008 [available http://www.curriculum.edu.au/leader/improving_student_achievement,2 5374.html?issueID=11603].

[8] R. E. Bennett, "Formative assessment: A critical review," Assessment in Education: Principles, Policy \& Practice, vol. 18, pp. 5-25, 2011.

[9] Budiyono, Pengantar Penilaian Hasil Belajar, Surakarta: Sebelas Maret University Press, 2015.

[10] J. Hattie and H. Timperley, "The power of feedback," Review of Educational Research, vol. 77, pp. 81-112, 2007.

[11] K. Dunn and S. Mulvenon, "A critical review of research on formative assessment: The limited scientific evidence of the impact of formative assessment in education," Practical Assessment, Research \& Evaluation, vol. 14, 2009 [availabel http://www.pareonline.net/pdf/v14n7.pdf].

[12] P. Black and D. Wiliam, "Assessment and classroom leaning," Assessment in Education, vol. 5, pp. 7-74, 1998.

[13] C. Magno and G. S. Lizada, "Features of classroom formative assessment," Educational Measurement and Evaluation Review, vol. 6, pp. 23- 31, 2015.

[14] E. Ong, H. Cabansag, and H. Sacolles, "Formative assessments as scaffolds to increase mathematics achievement of grade 11 students,"
Proceedings of DLSU Research Congress, Vol. 4, March 2016 [Presented at the DLSU Research Congress De La Salle University, Manila, Philippines, 2016].

[15] M. Goos, "Mathematics classroom assessment," in Encyclopedia of mathematics education, S. Lerman, Eds. Netherlands: Springer, 2014, pp. 413-417.

[16] D. Wiliam, "What is assessment for learning?," Studies in Educational Evaluation, vol 37, pp. 3-14, 2011

[17] M. Petit and J. Zawojewaski, "Formative assessment in elementary school mathematics classrooms," In Teaching and learning mathematics: Translating research for elementary school teachers, D. Lambdin, Eds. Reston, VA: National Council of the Teachers of Mathematics, 2010, pp. 73-79.

[18] R. Stiggins, "Assessment for learning: A key to motivation and achievement," Edge, vol. 2, pp. 3-19, 2006.

[19] S. Leahy, C. Lyon, M. Thompson, and D. Wiliam, "Classroom assessment: Minute by minute, day by day," Educational Leadership, vol. 63, pp. 19-24, 2005.

[20] S. Andersson and T. Palm, "Characteristics of improved formative assessment practice,' Education Inquiry, 2017 [DOI: 10.1080/20004508.2016.1275185]. 